\section{La virtud de la Justicia}

\section{y su precio en Verdad.}

Una reflexión sobre los Juicios a

las Juntas en Argentina, a la luz

de la Comisión de la Verdad y la

Reconciliación en Sudáfrica

Claudia Hilb

Claudia Hilb es Investigadora del CONICET, en el Instituto de Investigaciones Gino Germani, Facultad de Ciencias Sociales, Universidad de Buenos Aires.

e-mail: hilb@fibertel.com.ar

\section{Resumen}

A la luz de una contrastación de los "Juicios a las Juntas» en Argentina, y de la labor de la Comisión de Verdad y Reconciliación en Sudáfrica, el texto propone interrogar de qué manera la opción decidida por la justicia en Argentina puede haber tenido por correlato, observada veinticinco años más tarde, un cierto sacrificio o pérdida de la Verdad. Plantea la pregunta de si ese sacrificio es inevitable, se interroga sobre sus razones acerca de la posibilidad de que tal cuestionamiento pueda contribuir a restituir en parte dicha pérdida.

\section{Summary}

Focusing on the contrast between the "trials against the Juntas» in Argentina, and the Truth and Reconciliation Commission in South Africa, the text argues that the "post-1983» emphasis upon justice in Argentina might have entailed, viewed twenty-five years later, a certain sacrifice, a certain loss of truth. It raises the question to know if that sacrifice was simply necessary, it focuses on its motives, and finally, it raises the possibility that such a questioning could eventually contribute in partly restoring the loss in truth. 